
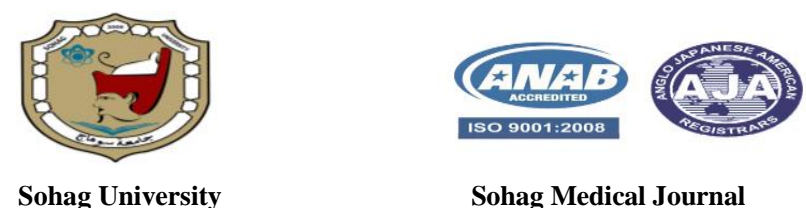

Sohag Medical Journal

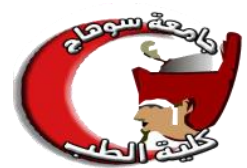

Faculty of Medicine

\title{
Knowledge, Attitude, Practice of Laboratory Technicians, and Nursing Staff about Hepatitis C Viral Infection in Sohag University Hospital.
}

\author{
Eman El-Sayed Reyad ". Haitham "Mohammad Al-Amir" Shahat ${ }^{2}$. \\ Ahmed Fathy Hamed Ahmed El Nahhas ${ }^{3}$, Eman Roshdy Mohammad ${ }^{3}$, \\ Nesreen A. Mohammed ${ }^{3 .}$
}

${ }^{1}$ Sohag Health Directorate, Ministry of Health, Egypt.

${ }^{2}$ Department of Internal Medicine, Faculty of Medicine, Sohag University, Sohag, Egypt.

${ }^{3}$ Department of Public Health and Community Medicine, Faculty of Medicine, Sohag

University, Sohag, Egypt.

\begin{abstract}
:
Background: Laboratory technicians and nursing staff are at high-risk for acquiring hepatitis $\mathrm{C}$ virus (HCV) infection. As no vaccination, knowledge, attitudes, the practice of Laboratory technicians, and nursing staff play a key role in the prevention of the spread of infection.
\end{abstract}

Aim: To determine the knowledge, attitude, the practice of laboratory technicians, and nursing staff concerning HCV infection in Sohag University Hospital.

Materials and Methods: The cross-sectional survey was conducted on 446 laboratory technicians and nursing staff working at Sohag University Hospital using a self-administered questionnaire.

Results: $56.5 \%$ of laboratory technicians, nursing staff had good knowledge, $65.02 \%$ had a positive attitude and $53.81 \%$ had bad practice toward HCV patients. Laboratory technicians have better knowledge, more positive attitudes and better practices than nursing staff.

Conclusion: Knowledge, attitudes, the practices about HCV among laboratory technicians, and nursing staff are matters of concern. Educational programs should be formulated to raise their awareness about HCV.

Key Words: Knowledge Attitude, Practice, Technicians, Nursing.

\section{Introduction:}

$\mathrm{HCV}$ is considered a worldwide health problem. It is estimated that 170 million persons $(2 \%-3 \%$ of the world's population) are having chronic HCV infection, and approximately 399000 people die each year from HCV [1]. Health care workers (HCWs) are potentially at high risk of blood-borne diseases such as hepatitis $B$ virus or $\mathrm{HCV}$. Needlestick injuries (NSIs) are the most common form of occupational exposure to blood and the most likely to transmit HCV [2]. Studies reported that the risk of $\mathrm{HCV}$ transmission among HCWs with NSIs has been 
estimated to $3-10 \%$, and this increases $>10$-fold if the source patient has high levels of virus load [3].

There are limited numbers of studies that may include different results regarding the evaluation of attitudes and practice of HCWs toward the patients with chronic HCV infection. Therefore, this study was conducted to determine the knowledge, attitude, and practice of laboratory technicians and nursing staff concerning HCV infection in Sohag University hospital.

\section{Methodology: \\ Ethical consideration:}

Before starting data collection ethical approval was obtained from the Scientific Research Ethics Committee of the Faculty of Medicine, Sohag University. In addition, official approval was obtained from the manager of Sohag University Hospital. During the data collection stage, informed consent was secured from each participant. This also included explanation of the purpose of the study to all the participants ensuring strict confi-dentiality and anonymity of all the collected data.

\section{Study design:}

The current study is a cross-sectional study conducted among the nursing staff and laboratory technicians in Sohag University Hospital from October 2018 to January 2019.

\section{Study population:}

The studied population was composed of laboratory technicians and nursing staff working at Sohag University Hospital which covered 72 laboratory technicians and 374 nurses from different departents and laboratories.

\section{Sample size:}

Total coverage of laboratory technicians and nursing staff in the hospital was carried out.

\section{Data collection procedure:}

After explaining the aim of the study and the questionnaire to the laboratory technicians and nursing staff, a questionnaire was distributed to the laboratory technicians and nursing staff who accept to participate in the study, and they were asked to fill them. The required time needed to fill the questionnaire was $15-20$ min.

\section{Study instrument:}

A structured interviewing questionnaire was used in this study. It consisted of four sections: section 1 for the sociodemographic characteristics, section 2 for detection of knowledge of the participants about $\mathrm{HCV}$ infection, section 3 for their attitude toward HCV infection, and section 4 for their practice toward chronic HCV infected patients.

Forty-five questions were asked to the participants: 6 questions related to name, age, gender, occupation, working years, department; 25 questions related to the knowledge about HCV infection (14 questions about $\mathrm{HCV}$ transmission and 11 questions about $\mathrm{HCV}$ nature, clinical picture, and management); 5questions related to the description of attitude toward the patients with $\mathrm{HCV} ; 2$ questions related to attitude and willingness to deal and treat the patients with hepatitis C; 2 questions related to attitudes and the fears about contact with $\mathrm{HCV}$; and 5 questions related to practice toward $\mathrm{HCV}$ patients.

The level of knowledge of HCWs was evaluated with correct responses to total 25 questions given to them. The mean knowledge score was used for discrimination [4]. Scores over the mean kno- 
wledge score were defined to be good knowledge level and the scores below the mean knowledge score were defined to be poor.

A five-point Likert scale ranging from strongly agree to strongly disagree was used in the questionnaire to evaluate the attitudes and practices of HCWs toward the patients with hepatitis $C$. the mean attitude and knowledge scores were used to classify the participants into groups with a positive attitude or with negative attitude and groups with good practice or with bad practice [4].

A pilot study was conducted on 10 laboratory technicians and 40 nurses that had not been included in the study group to assess the time, content validity of the tool and to detect any problem peculiar to the data collection tool that may face the researcher.

\section{Statistical analysis:}

Data entry and analysis were done using SPSS software for Windows (version 16.0; SPSS Inc., Chicago, Illinois, USA). The calculation of frequency and percentages for the classified data, mean, and standard deviations were obtained. While statistical differences between the classes were done with the chi-square test, and mean differences between the groups were investigated by using the Mann-Whitney U test and Kruskal-Wallis tests (as the data showed non-parametric distribution using tests of normality). A P-value of less than 0.05 was used as the cutoff of statistical significance.

\section{Results:}

The current study included 446 participants [72 laboratory technicians (16.1\%), and $374(83.9 \%)$ nursing staff] who were employed in Sohag university hospital. $87.4 \%$ were females and $12.6 \%$ were males. $38.6 \%$ have experienced less than 6 years, 24\% between 6-10 years, and $37.4 \%$ more than 10 years (Table -1$)$.

\begin{tabular}{||c|c||}
\hline Demographic data & Number (\%) \\
\hline Age (Mean \pm SD): & $29.13 \pm 5.82$ \\
<31y & $293(65.7 \%)$ \\
31-40 y & $135(30.3 \%)$ \\
>40 y & $18(4 \%)$ \\
\hline Gender: & \\
Female & $390(87.4 \%)$ \\
Male & $56(12.6 \%)$ \\
\hline Health care group: & \\
Nursing staff & $374(83.9 \%)$ \\
Lab technician & $72(16.1 \%)$ \\
\hline Working years: & \\
<6 y & $172(38.6 \%)$ \\
6-10 y & $107(24 \%)$ \\
>10 y & $167(37.4 \%)$ \\
\hline Department: & \\
Non-surgical & $196(43.9 \%)$ \\
Surgical & $178(39.9 \%)$ \\
Laboratory & $72(16 \%)$ \\
\hline \multicolumn{2}{|l}{} \\
\hline \multicolumn{2}{|l}{}
\end{tabular}

Table (1): Distribution of the studied nursing staff and lab technicians according to their socio-demographic characteristics, Sohag University Hospital, 2018/2019.

In this study, above $90 \%$ know that HCV can transmit through surgical instruments and can't be transmitted through personal contacts like handshaking and kissing. $85.4 \%$ of the studied group was aware of the presence of available pharmaceutical treatment, only $35 \%$ of them have the right knowledge about the presence of prophylactic treatment for NSI (Table-2). 


\begin{tabular}{|c|c|c|c|c|c|}
\hline \multirow[b]{2}{*}{ Item } & \multicolumn{2}{|c|}{ Nursing staff } & \multicolumn{2}{|c|}{ Lab technicians } & \multirow[b]{2}{*}{ P-value } \\
\hline & $\begin{array}{l}\text { Incorrect } \\
\text { answer } \\
\mathbf{N}(\%)\end{array}$ & $\begin{array}{l}\text { Correct } \\
\text { answer } \\
\mathbf{N}(\%)\end{array}$ & $\begin{array}{l}\text { Incorrect } \\
\text { answer } \\
\mathbf{N}(\%)\end{array}$ & $\begin{array}{l}\text { Correct } \\
\text { answer } \\
\text { N }(\%)\end{array}$ & \\
\hline It is a viral infection & $54(14.4 \%)$ & $320(85.6 \%)$ & $11(15.3 \%)$ & $61(84.7 \%)$ & 0.85 \\
\hline $\begin{array}{l}\text { Transmission through } \\
\text { surgical instruments }\end{array}$ & $27(7.2 \%)$ & $347(92.8 \%)$ & $5(6.9 \%)$ & $67(93.1 \%)$ & 0.93 \\
\hline $\begin{array}{l}\text { Transmission through } \\
\text { personal contact }\end{array}$ & $17(4.5 \%)$ & $357(95.5 \%)$ & $9(12.5 \%)$ & $63(87.5 \%)$ & $0.01 *$ \\
\hline $\begin{array}{l}\text { Risk of transmission } \\
\text { through NSI is 30- } \\
50 \%\end{array}$ & $193(51.6 \%)$ & $181(48.4 \%)$ & $37(51.4 \%)$ & $35(48.6 \%)$ & 0.97 \\
\hline $\begin{array}{l}\text { It can lead to liver } \\
\text { cirrhosis }\end{array}$ & $62(16.6 \%)$ & $312(83.4 \%)$ & $18(25 \%)$ & $54(75 \%)$ & 0.09 \\
\hline $\begin{array}{l}\text { It is a mutation of } \\
\mathrm{HBV}\end{array}$ & $103(27.5 \%)$ & $271(72.5 \%)$ & $17(23.6 \%)$ & $55(76.4 \%)$ & 0.49 \\
\hline $\begin{array}{l}\text { It increases risk of } \\
\text { liver cancer }\end{array}$ & $158(42.2 \%)$ & $216(57.8 \%)$ & $27(37.5 \%)$ & $45(62.5 \%)$ & 0.45 \\
\hline 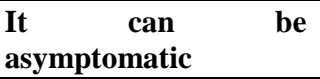 & $178(47.6 \%)$ & $196(52.4 \%)$ & $17(23.6 \%)$ & $55(76.4 \%)$ & $<0.001 *$ \\
\hline $\begin{array}{lr}\text { Symptoms } & \text { appear } \\
\text { immediately } & \text { after } \\
\text { getting infection } & \end{array}$ & $125(33.4 \%)$ & $249(66.6 \%)$ & $12(16.7 \%)$ & $60(83.3 \%)$ & $0.01 *$ \\
\hline $\begin{array}{l}\text { There is a vaccine for } \\
\text { it }\end{array}$ & $235(62.8 \%)$ & $139(37.2 \%)$ & $31(43.1 \%)$ & $41(56.9 \%)$ & $<0.001 *$ \\
\hline $\begin{array}{l}\mathrm{HCV} \text { pre-marriage } \\
\text { tests are mandatory }\end{array}$ & $102(27.3 \%)$ & $272(72.7 \%)$ & $35(48.6 \%)$ & $37(51.4 \%)$ & $<0.001 *$ \\
\hline $\begin{array}{l}\text { There is prophylactic } \\
\text { treatment for NSI }\end{array}$ & $255(68.2 \%)$ & $119(31.8 \%)$ & $35(48.6 \%)$ & $37(51.4 \%)$ & $<0.001 *$ \\
\hline $\begin{array}{l}\text { There is a } \\
\text { pharmaceutical } \\
\text { treatment }\end{array}$ & $54(14.4 \%)$ & $320(85.6 \%)$ & $11(15.3 \%)$ & $61(84.7 \%)$ & 0.85 \\
\hline $\begin{array}{l}\text { Positive people should } \\
\text { restrict alcohol intake }\end{array}$ & $83(22.2 \%)$ & $291(77.8 \%)$ & $25(34.7 \%)$ & $47(65.3 \%)$ & $0.02 *$ \\
\hline
\end{tabular}

Table (2): Knowledge about HCV nature, clinical picture, management among the studied nursing staff and laboratory technicians, Sohag University Hospital, 2018/ 2019.

Note: Significance of difference is measured with Pearson's chi-square test.

*Indicates significance at the 0.05 level.

Regarding their attitude and practice toward HCV patients, none of the studied HCWs disagrees strongly with testing all patients for HCV before receiving health care services, wearing pair of gloves wh- en dealing with HCV patients, using additional infection control measures with $\mathrm{HCV}$ patients, and the fact that following infection control measures are protective against HCV. (Table- 3, 4). 
SOHAG MEDICAL JOURNAL

Vol. 25 No. 1 Jan 2021
Knowledge, Attitude, Practice of Laboratory Technicians

Eman El-Sayed Reyad

\begin{tabular}{|c|c|c|c|c|c|c|c|c|c|c|c|}
\hline \multirow[b]{2}{*}{ Item } & \multicolumn{5}{|c|}{ Nursing staff } & \multicolumn{5}{|c|}{ Lab technicians } & \multirow[t]{2}{*}{$\begin{array}{c}\text { P- } \\
\text { Value }\end{array}$} \\
\hline & 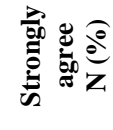 & 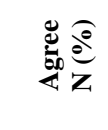 & 章 & 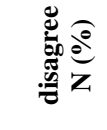 & 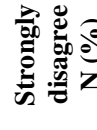 & 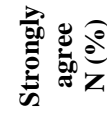 & 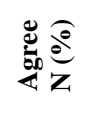 & 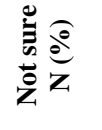 & 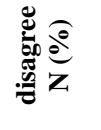 & 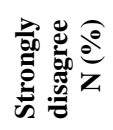 & \\
\hline $\begin{array}{l}\text { Testing all patients } \\
\text { for HCV before } \\
\text { receiving health } \\
\text { care }\end{array}$ & $\begin{array}{c}194 \\
(51.9 \%)\end{array}$ & $\begin{array}{c}168 \\
(44.9 \%)\end{array}$ & $\begin{array}{c}6 \\
(1.6 \%)\end{array}$ & $\begin{array}{c}6 \\
(1.6 \%)\end{array}$ & $0(0 \%)$ & $\begin{array}{c}59 \\
(81.9 \%)\end{array}$ & $\begin{array}{c}13 \\
(18.1 \%)\end{array}$ & $0(0 \%)$ & $0(0 \%)$ & $0(0 \%)$ & $\stackrel{<}{<.001 *}$ \\
\hline $\begin{array}{l}\text { Restricting contact } \\
\text { of positive HCWs } \\
\text { with patients }\end{array}$ & $\begin{array}{c}59 \\
(15.8 \%)\end{array}$ & $\begin{array}{c}176 \\
(47.1 \%)\end{array}$ & $\begin{array}{c}24 \\
(6.4 \%)\end{array}$ & $\begin{array}{c}114 \\
(30.5 \%)\end{array}$ & $\begin{array}{c}1 \\
(0.3 \%)\end{array}$ & $\begin{array}{c}6 \\
(8.3 \%)\end{array}$ & $\begin{array}{c}43 \\
(59.7 \%)\end{array}$ & $\begin{array}{c}2 \\
(2.8 \%)\end{array}$ & $\begin{array}{c}21 \\
(29.2 \%)\end{array}$ & $0(0 \%)$ & 0.21 \\
\hline $\begin{array}{ll}\text { Not having skills } \\
\text { for dealing with } \\
\text { HCV patients }\end{array}$ & $\begin{array}{c}59 \\
(15.8 \%)\end{array}$ & $\begin{array}{c}180 \\
(48.1 \%)\end{array}$ & $\begin{array}{c}91 \\
(24.3 \%)\end{array}$ & $\begin{array}{c}43 \\
(11.5 \%)\end{array}$ & $\begin{array}{c}1 \\
(0.3 \%)\end{array}$ & $\begin{array}{c}120 \\
(16.7 \%)\end{array}$ & $\begin{array}{c}44 \\
(61.1 \%)\end{array}$ & $\begin{array}{c}8 \\
(11.1 \%)\end{array}$ & $\begin{array}{c}8 \\
(11.1 \%)\end{array}$ & $0(0 \%)$ & 0.14 \\
\hline $\begin{array}{l}\text { Following infection } \\
\text { control measures is } \\
\text { protective against } \\
\text { HCV }\end{array}$ & $\begin{array}{c}188 \\
(50.3 \%)\end{array}$ & $\begin{array}{c}146 \\
(39 \%)\end{array}$ & $\begin{array}{c}40 \\
(10.7 \%)\end{array}$ & $0(0 \%)$ & $0(0 \%)$ & $\begin{array}{c}31 \\
(43.1 \%)\end{array}$ & $\begin{array}{c}33 \\
(45.8 \%)\end{array}$ & $\begin{array}{c}8 \\
(11.1 \%)\end{array}$ & $0(0 \%)$ & $0(0 \%)$ & 0.51 \\
\hline $\begin{array}{l}\text { Low possibility of } \\
\text { infection with HCV } \\
\text { during hospital } \\
\text { work }\end{array}$ & $\begin{array}{c}72 \\
(19.3 \%)\end{array}$ & $\begin{array}{c}44 \\
(11.8 \%)\end{array}$ & $\begin{array}{c}68 \\
(18.2 \%)\end{array}$ & $\begin{array}{c}153 \\
(40.9 \%)\end{array}$ & $\begin{array}{c}37 \\
(9.9 \%)\end{array}$ & $0(0 \%)$ & $\begin{array}{c}3 \\
(4.2 \%)\end{array}$ & $\begin{array}{c}2 \\
(2.8 \%)\end{array}$ & $\begin{array}{c}50 \\
(69.4 \%)\end{array}$ & $\begin{array}{c}17 \\
(23.6 \%)\end{array}$ & $\begin{array}{c}< \\
0.001 *\end{array}$ \\
\hline
\end{tabular}

Table (3): Attitude of the studied nursing staff and laboratory technicians toward HCV patients,

Sohag University Hospital, 2018/ 2019.

The significance of the difference is measured with Pearson's chi-square test.

*Indicates significance at the 0.05 level.

\begin{tabular}{||l|c|c|c|c|c|c|c|c||c||}
\hline \hline & \multicolumn{3}{|c|}{ Nursing staff } & \multicolumn{3}{|c||}{ Lab technicians } \\
value
\end{tabular}

Table (4): Practice of the studied nursing staff and laboratory technicians toward HCV patients,

Sohag University Hospital, 2018/ 2019.

Note: Significance of difference is measured with Pearson's chi-square test. 
*Indicates significance at the 0.05 level. In this study, there is no significant difference between total knowledge score and participants' age, occupation nor department. This study showed that there is a negligible relationship between the participants' total knowledge score, their attitude, and practice scores toward patients with HCV (Table- 5). However, $76 \%$ of the studied HCWs reported that they will treat and/or investigate patients with $\mathrm{HCV}, 53.6 \%$ reported their wish not to deal with HCV patients. (Table6).

This study revealed that Lab technicians have better knowledge scores about $\mathrm{HCV}$, more positive attitude scores, and better practice scores toward HCV patients than nursing staff (Table- 7).

\begin{tabular}{|c|c|}
\hline & Total knowledge score \\
\hline Total attitude score: & \\
r & 0.17 \\
P value & 0.00 \\
\hline Total practice score: & \\
P value & 0.03 \\
\hline
\end{tabular}

Table (5): Spearman correlation between total knowledge score about $\mathrm{HCV}$, total attitude and practice scores toward $\mathrm{HCV}$ patients among the studied nursing staff and lab technicians, Sohag University Hospital, 2018/ 2019.

\begin{tabular}{|c|c|c|}
\hline Item & $\begin{array}{l}\text { Yes } \\
\text { N }(\%)\end{array}$ & $\begin{array}{l}\text { No } \\
\text { N }(\%)\end{array}$ \\
\hline Liking to deal with HCV patients & $\begin{array}{l}207 \\
(46.4 \%)\end{array}$ & $\begin{array}{l}239 \\
(53.6 \%)\end{array}$ \\
\hline $\begin{array}{l}\text { Willingness to treat } \mathrm{HCV} \\
\text { patients }\end{array}$ & $\begin{array}{l}339 \\
(76 \%)\end{array}$ & $\begin{array}{l}107 \\
(24 \%)\end{array}$ \\
\hline Afraid of catching HCV infection & $\begin{array}{l}413 \\
(92.6 \%)\end{array}$ & $\begin{array}{l}33 \\
(7.4 \%)\end{array}$ \\
\hline $\begin{array}{l}\text { Afraid of already being } \mathrm{HCV} \\
\text { positive }\end{array}$ & $\begin{array}{l}331 \\
(74.2 \%)\end{array}$ & $\begin{array}{l}115 \\
(25.8 \%)\end{array}$ \\
\hline
\end{tabular}

Table (6): Distribution of the studied nursing staff, lab technicians according to their attitude, willingness to treat $\mathrm{HCV}$ patients, and their fear of having or catching $\mathrm{HCV}$, Shag University

\begin{tabular}{||c|c|c|c||}
\hline Item & $\begin{array}{c}\text { Nursing } \\
\text { staff } \\
\text { n (\%) }\end{array}$ & $\begin{array}{c}\text { Lab } \\
\text { technicians } \\
\text { n }(\%)\end{array}$ & P value \\
\hline $\begin{array}{c}\text { Knowledge: } \\
\text { Poor }\end{array}$ & $164(43.9 \%)$ & $30(41.7 \%)$ & 0.73 \\
Good & $210(56.1 \%)$ & $42(58.3 \%)$ & \\
\hline $\begin{array}{c}\text { Attitude: } \\
\text { Negative }\end{array}$ & $151(40.4 \%)$ & $5(6.9 \%)$ & $<0.001^{*}$ \\
Positive & $223(59.6 \%)$ & $67(93.1 \%)$ & \\
\hline $\begin{array}{c}\text { Practice: } \\
\text { Bad }\end{array}$ & $213(57 \%)$ & $27(37.5 \%)$ & $<0.001 *$ \\
Good & $161(43 \%)$ & $45(62.5 \%)$ & \\
\hline
\end{tabular}

Table (7): Comparison between the studied nursing staff, lab technicians regarding their knowledge, attitude, and practice scores about HCV, Sohag University Hospital, 2018/ 2019.

Note: Significance of difference is measured with Pearson's chi-square test. *indicates significance at the 0.05 level.

\section{Discussion:}

HCV can be spread in clinical settings from patient to patient, from patient to doctor, and from doctor to patient which leads to 8 out of 10 new infections occurring in hospitals and clinics [5].

The current study has shown that the mean age of the participants is $29.13 \pm$ 5.82 years, $65.7 \%$ were below 31 years. The majority of the studied HCWs are females and work as nurses. Regarding the health department, they belong to, $43.9 \%$ work at non-surgical departments while $16.1 \%$ works at labs. This was similar to the study of Van de Mortel. [6], as $43 \%$ of their participants in their study were younger than 30 years old, while the mean age of the participants in the study of Shoman et al. [7], were (34 \pm 9.4$)$ years for the physicians, $(33 \pm 10)$ years for the nurses, and $(38.5 \pm 8.6)$ years for the traditional providers. 
Regarding HCWs knowledge about HCV transmission in our study, they answered most of the related questions correctly. In line with our results, Shoman et al. [7], reported in their study that around $97 \%$ of the physicians, $91 \%$ of nursing staff, and $83 \%$ of traditional providers reported that medical workers have a high risk to be infected with $\mathrm{HCV}$ and contaminated blood transfusion is a common method of HCV transmission. These percentages are higher than the results of the Kuwaiti study, which reported that $74 \%$ of the physicians, nursing staff, and paramedical staff considered health care workers at high-risk populations [8]. The possible reason for this difference may be the higher perception of risk and fear of $\mathrm{HCV}$ infection among Egyptian HCWs as $\mathrm{HCV}$ is endemic in Egypt, and Egypt has the highest prevalence of HCV worldwide [5]. Furthermore, Bianco et al. [9], found in their study that $92 \%$ of Italian nurses knew that sharing razors or toothbrushes is the way of transmission of HCV.

Regarding their attitude and practice toward HCV patients, in line with this study, Shoman et al. [7], reported that the majority of the participant physicians (99\%), nurses $(78 \%)$, and traditional providers $(71 \%)$ realized the importance of infection control guidelines during a blood transfusion. These percentages are higher than the results of Kabinda et al. [10], who conducted a cross-sectional study to assess knowledge, attitude practice of the doctors, nurses, and midwives from 12 general reference hospitals, 11 hospitals and 65 health centers in Congo, and found that $60 \%$ of them knew the ultimate control measures before blood transfusion. However, the results of the present study are higher than the results of Yaghi et al. [8], who found that $80 \%$ of the physicians, nursing staff, and paramedical staff believed in wearing gloves, and also higher than the results of Rasslan et al. [11], who conducted a cross-sectional study among 404 physicians, nurses and technicians in Ain Shams University hospitals and reported that $93 \%$ of them knew the importance of wearing gloves. This high percentage of correct knowledge may be due to high attendance to infection control courses among the Lab technicians and nurses of the present study. Therefore, training courses play an important role in improving the knowledge of health care workers. In the study of Shoman et al. [7], around 93\% of the participating physicians, $90 \%$ of nurses, and $80 \%$ of the traditional providers knew that $\mathrm{HCV}$ can be prevented. Regarding fears of catching or having $\mathrm{HCV}$ infection, HCWs who aren't afraid of being $\mathrm{HCV}$ positive reported a more positive attitude compared to those who are afraid. There is no significant relationship between the willingness of $\mathrm{HC}$ Ws to treat $\mathrm{HCV}$ patients, their fear of catching $\mathrm{HCV}$, and their attitude toward $\mathrm{HCV}$ patients. In contrast to the current results, Joukar et al. [4], found a statistically significant difference between the doctors, nursing staff, and paramedical staff regarding the observational practice score, however, they found that there was a statistically significant difference between the physicians and the nursing staff regarding the total practice score $(\mathrm{p}<0.05)$ with the physicians had a higher percentage of correct practice than the nursing staff. These results also agree with the results of Setia et al. [12], who reported that there was a significant difference between the physicians and the nursing staff regarding total practice score. 
The study revealed that Lab technicians have a better knowledge score about $\mathrm{HCV}$, a more positive attitude score, and a better practice score toward $\mathrm{HCV}$ patients than nursing staff. Similar to the results of this study, Shoman et al. [7], reported in their study that physicians had the best knowledge about the cause of HCV (100\%) followed by the nurses (94\%) then the traditional providers had the least correct knowledge. These percentages are higher than the results of Van de Mortel. [6], who conducted a cross-sectional study among Australian physicians, nursing staff, paramedical staff and reported that $72 \%$ of them knew that hepatitis $\mathrm{C}$ is caused by a virus. The possible cause of that difference is that $43 \%$ of the participants in de Mortel study were younger than 30 years old, while the mean age of the participants in the study of Shoman et al. [7], were $(34 \pm 9.4)$ years for the physicians, $(33 \pm 10)$ years for the nursing staff, (38.5 \pm 8.6$)$ years for the traditional providers, and their age reflected on their years of experience.

\section{Limitations:}

This stud is a self-reported questionnaire-based study. Therefore, in this study, the subjective self-reported information should be carefully evaluated, because there was no validation of selfreported behavior against the actual clinical behavior. Furthermore, absence of some workers as data couldn't be collected from those workers and they were excluded from data collection and analysis because we did not coordinate a specific time and place for filling a questionnaire.

\section{Conclusion and recommendations:}

This study highlights the knowledge, attitude, and practice about HCV among laboratory technicians and nursing staff in Sohag university hospital. Health care managers, as well as the government, should take more measures by running awareness programs to strengthen the Knowledge, attitude and improve the practice of HCWs especially of nursing staff as the cost of treating patients with $\mathrm{HCV}$ infection far outweighs the cost of implementing prevention programs as educational programs about HCV infections. It is necessary to increase the level of quality of training among HCWs as it remains the key preventive measure for improving HCWs' compliance with improved standard precautions to prevent discrimination, prejudice towards the infection and the patients.

\section{Acknowledgments:}

The authors thank all laboratory technicians and nursing staff for their cooperation in answering and completing the questionnaires needed for conducting the research.

\section{Conflict of interest:}

Authors have no conflict of interests, an$\mathrm{d}$ the work was not supported or funded by any organization.

\section{References:}

1. WHO. Hepatitis C Retrieved 13 Sep 2018, from http://www.who.int/newsroom/fact-sheets/detail/hepatitis-c.

2. Bijani, B., \& Azimiyan, J. Epidemiology and risk factors of needle stick injuries among nurses in Bou-Ali Sina teaching hospital, Qazvin. J. shahid Beheshti nursing and midwifery 2018; 22(78), 1-8.

3. Wicker, S., Cinatl, J., Berger, A., et al. Determination of Risk of Infection with Blood-borne Pathogens Following a Needlestick Injury in Hospital Workers. The Annals of 
Occupational Hygiene, 2008; 52(7), 615-622.

4. Joker F, Mansour-Ghanaei F, Soati F, Meskink-honda P. Knowledge levels and attitudes of health care professionals toward patients with hepatitis $\mathrm{C}$ infection. World $\mathrm{J}$ Gastroenterology 2012; 18: 2238-44.

5. World health organization: Hepatitis C fact sheets 2015; http://www.who.int/media centre /factsheets/fs164/en/.

6. Van de Mortel TF. Health care workers' knowledge of hepatitis C and attitudes towards patients with hepatitis C: a pilot study. Aust J Adv Nurs 2002; 20: 13-9.

7. Shoman AE, Somaia I. Salama, et al. Knowledge Health Care and Practice of Physicians, Nurses and Traditional Providers about Hepatitis C Virus Infection in Six Egyptian Governorates. The Egyptian Journal of Community Medicine October 2015Vol. 33 No. 4.

8. Yaghi $S A$, burial Al-Habib $E$ S, Lia S A, et al. Knowledge, attitude, and behavior of primary health care workers about hepatitis C, Kuwait. Greener J Med Science 2012; 2 (4): 84-91.
9. Bianco A, Bova F, Nobile CG, et al. Collaborative Working Group. Health-care workers and prevention of hepatitis $\mathrm{C}$ virus transmission: exploring knowledge, attitudes and evidence-based practices in hemodialysis units in Italy. BMC Infectious disease 2013; 13: 76.

10. Kabinda J M, Miyanaga SA, Donnan P, et al. Knowledge, Attitudes and Practices of Medical and Paramedical Staff in Blood Transfusion in the Democratic Republic of Congo. Open J Prev Med. 2014; 4(1): 672-680.

11. Russian O, Salama S, Aboul Fotouh A, et al. Safe injection practices among Health-Care Workers in Ain Shams University hospitals. MSC thesis: Faculty of Medicine. Ain Shams University 2011.

12. Setia S, Gambhir R, Kapoor V, et al. Attitudes and Awareness Regarding Hepatitis B and Hepatitis C Amongst Healthcare Workers of a Tertiary Hospital in India. Annals of Med and Health Science Research 2014; 3(4): 551-558. 